\title{
El patrimonio inmaterial en la Sierra de Cádiz: aproximación a los rituales festivos
}

Rosa Satué López | antropóloga

URL de la contribución <www.iaph.es/revistaph/index.php/revistaph/article/view/3732>

\section{RESUMEN}

Es la comarca situada más al norte de la provincia. Aunque su economía sigue siendo esencialmente agraria, el sector turístico tiene un peso cada vez mayor en la economía y se nutre de la buena conservación del entorno natural y la belleza de sus pueblos y, cada vez más, de la existencia de un patrimonio cultural vivo, variado y diferenciado de otras zonas.

En este artículo abordamos los rituales festivos, una parte muy significativa del patrimonio inmaterial de la Sierra de Cádiz. Se trata, en su mayoría, de rituales festivo-ceremoniales religiosos, normalmente en torno a la imagen de una virgen o un santo, como símbolos de identificación colectiva. Pero también encontramos celebraciones profanas, carnavales y ferias, así como fiestas de nueva creación. Los rituales festivos más generalizados son la Semana Santa, las romerías, el corpus, las ferias y las fiestas patronales.

\section{Palabras clave}

Andalucía | Cádiz (Provincia) | Patrimonio inmaterial | Rituales festivos | Romerías | Sierra de Cádiz | 


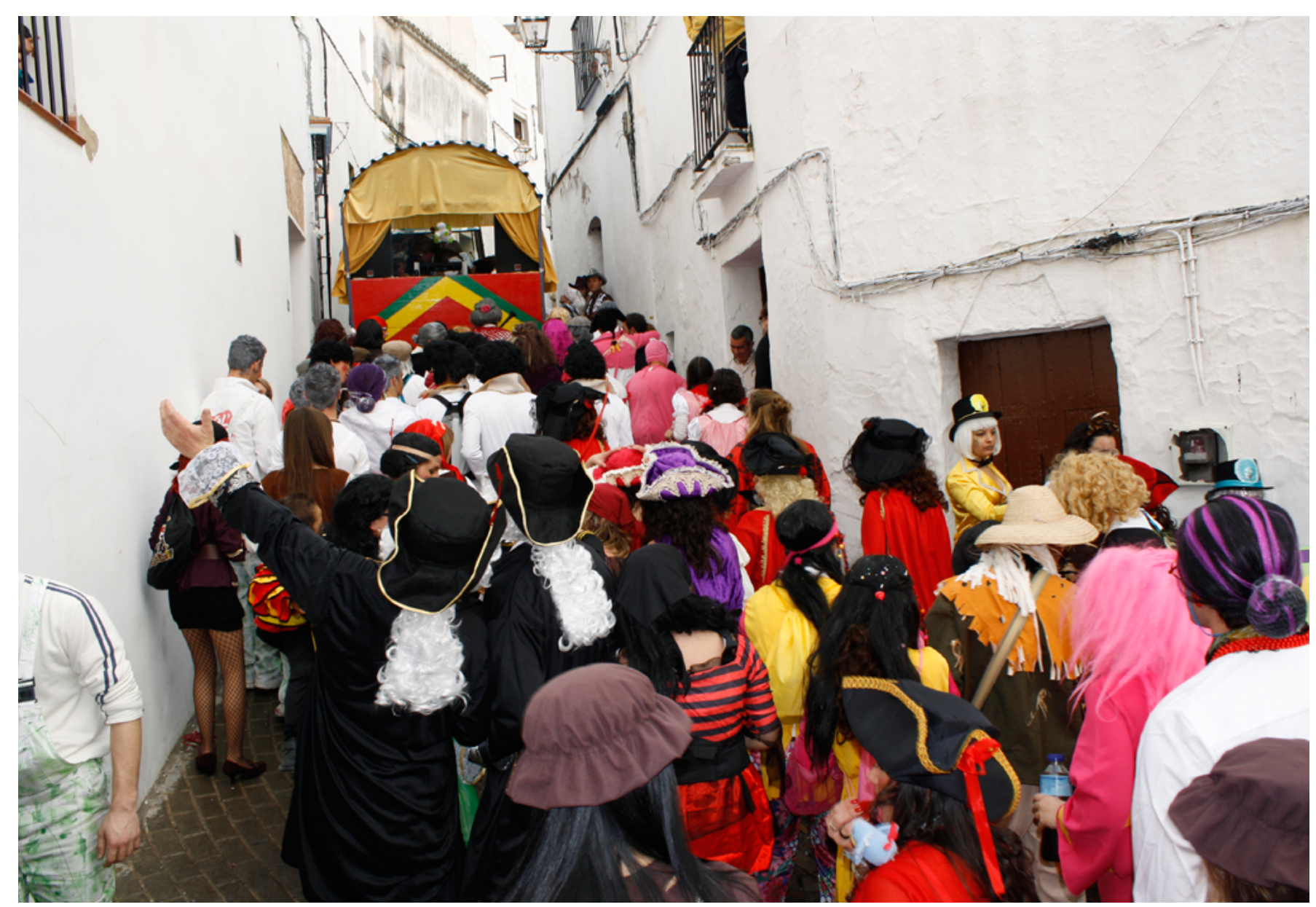

Cabalgata de Carnaval de Arcos de la Frontera | foto Fondo Gráfico IAPH (Rosa Satué López), para todas las imágenes del artículo 
La Sierra de Cádiz es la comarca situada más al norte de la provincia. Sus límites terminan donde comienzan las comarcas de la Campiña de Jerez, la Serranía de Ronda, el Bajo Guadalquivir y la Sierra Sur de Sevilla. Posee una enorme variedad de valores paisajísticos y ambientales debido a su geomorfología, caracterizada por la transición progresiva desde los terrenos de campiña de la zona occidental (sierra baja) a los paisajes más propiamente de montaña de la Sierra de Grazalema, en la parte más oriental (sierra alta). Tiene una superficie de $1.998 \mathrm{~km} 2$ y la componen los siguientes municipios: Alcalá del Valle, Algar, Algodonales, Arcos de la Frontera, Benaocaz, Bornos, El Bosque, Espera, El Gastor, Grazalema, Olvera, Prado del Rey, Puerto Serrano, Setenil de las Bodegas, Torre Alháquime, Ubrique, Villaluenga del Rosario y Villamartín.

La economía de esta zona sigue siendo esencialmente agraria, salvo en algunos municipios como Ubrique. En la sierra baja existe un equilibrio entre las tierras dedicadas a cultivos, cereal y olivar predominantemente, y los usos ganaderos y forestales del espacio. Mientras que en la sierra alta el porcentaje de tierras cultivadas es sólo testimonial y es el sector ganadero, con la explotación de razas autóctonas caprinas (payoya), ovinas (merina grazalemeña) y bovinas (retinta y pajuna), el pilar básico de la economía.

En cuanto al sector secundario, Ubrique concentra la mayor parte de las industrias de su área y está especializada en el tratamiento de la piel y la marroquinería, con las consiguientes empresas auxiliares. Vinculados al sector de la piel están Prado del Rey y, en menor medida, Benaocaz y El Bosque. Tanto Prado del Rey como Benamahoma conservan empresas dedicadas tradicionalmente a la fabricación de muebles artesanales y en Grazalema pervive una fábrica de mantas artesanales, reducto del importante complejo industrial que se desarrolló en este municipio en el pasado. Con todo, la

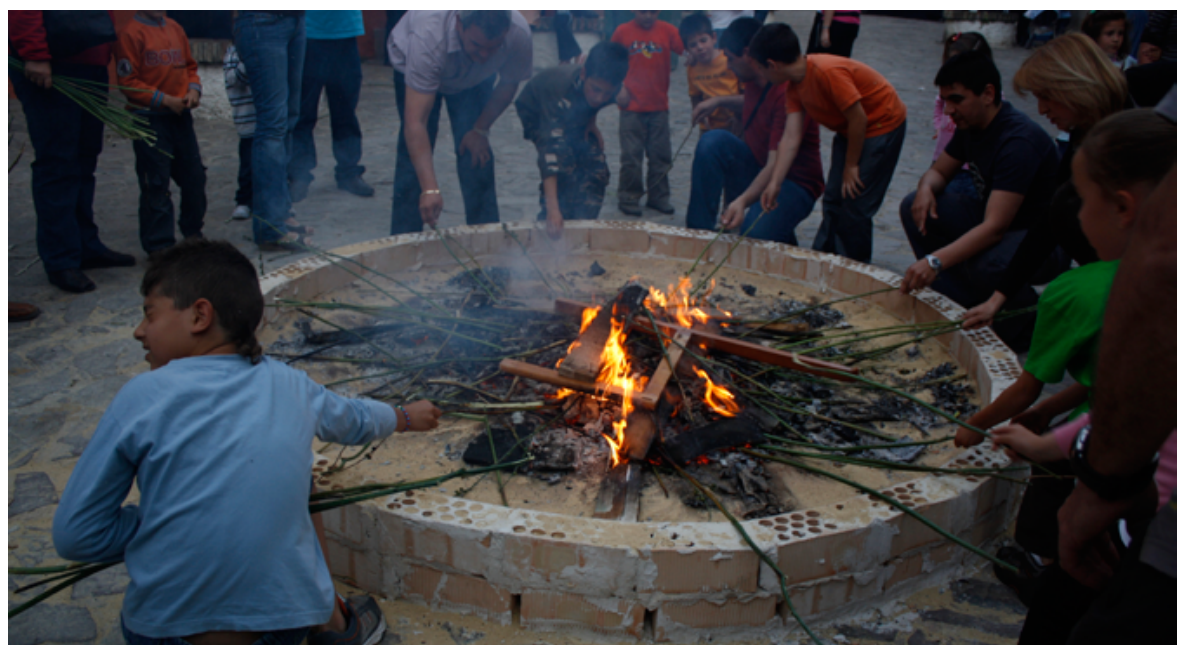


actividad productiva con mayor presencia en estos municipios gaditanos es la industria agroalimentaria, especialmente la relacionada con productos cárnicos (embutidos y chacinas) y lácteos (quesos) procedentes de la cabaña autóctona, además de aceite de oliva, miel, vino y mermelada, entre otros.

El sector turístico tiene un peso creciente en la economía de la comarca. La declaración de Reserva de la Biosfera por la UNESCO de la Sierra de Grazalema en 1977 y, posteriormente, la creación del Parque Natural en 1984, significó un impulso para el desarrollo turístico de las poblaciones que integran este territorio. La oferta turística se amplió más tarde con la promoción de la ruta de los Pueblos Blancos, en la que están presentes todos los pueblos de la Sierra de Cádiz. La demanda turística se nutre de la buena conservación del entorno natural y la belleza de sus pueblos y, cada vez más, de la existencia de un patrimonio cultural vivo, variado y diferenciado de otras zonas.

El patrimonio inmaterial de la Sierra de Cádiz es un ejemplo más de la riqueza y diversidad de la cultura andaluza. No es posible abundar en su conjunto y, por ello, nos detendremos en una parte significativa del mismo: los rituales festivos. La mayor parte de las celebraciones que encontramos en la sierra gaditana corresponde, como es común a todo el territorio andaluz, a rituales festivo-ceremoniales religiosos, normalmente en torno a la imagen de una virgen o un santo, referentes de gran importancia en Andalucía como símbolos de identificación colectiva. Pero, junto a ellos, también es posible encontrar celebraciones profanas, carnavales y ferias, así como fiestas de nueva creación.

Los rituales y fiestas están insertos en procesos históricos concretos y, por tanto, sujetos a evoluciones y modificaciones derivadas de su continua readaptación a los nuevos contextos. En concreto, los fuertes cambios que se introdujeron en el modelo productivo del país a partir de finales de los años

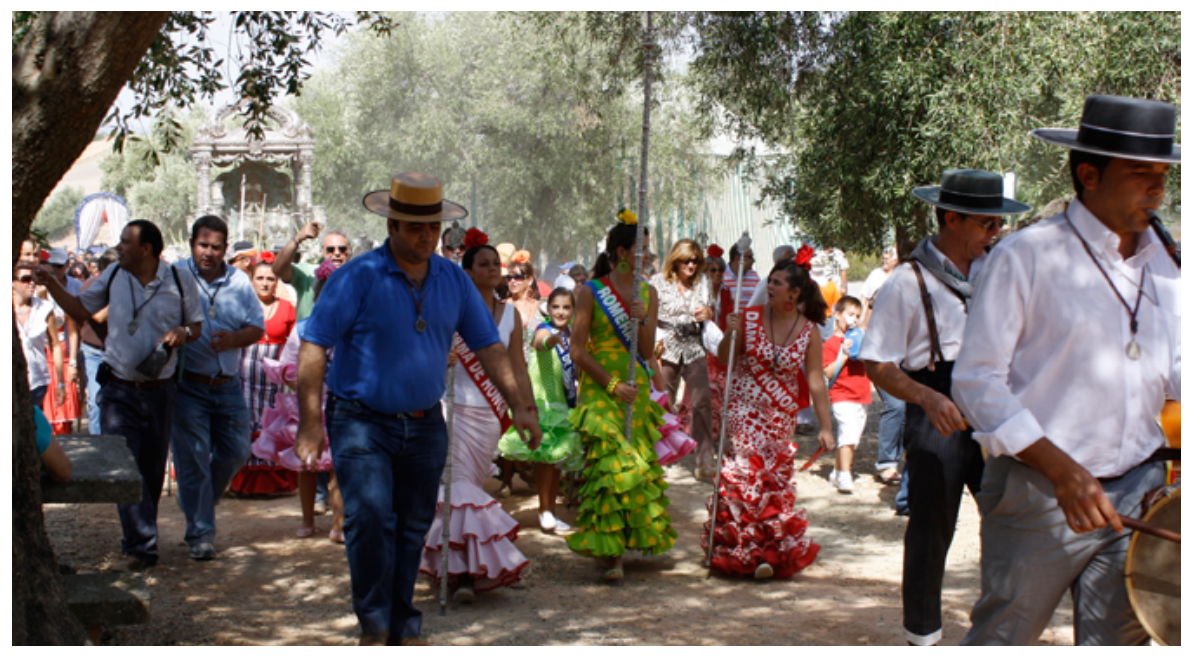

Romería de la Virgen de las Montañas de Villamartín 

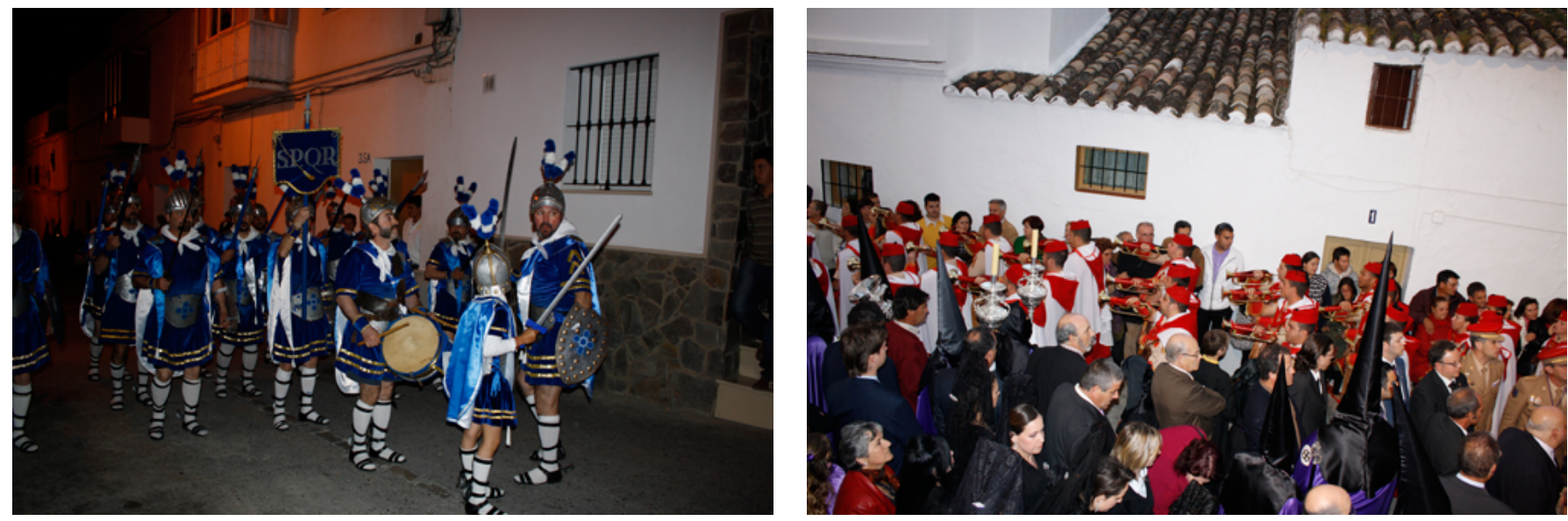

Armaos de San Antonio de Arcos de la Frontera (arriba)

Procesión de los Negros de Setenil de las Bodegas (derecha)

cincuenta del pasado siglo, con la implantación del Plan de Estabilización, y el desarrollismo económico afectaron de una manera determinante al mundo rural y, especialmente, a los pueblos de las sierras andaluzas, que experimentaron un rápido proceso de despoblamiento. En la Sierra de Cádiz fue numerosa la emigración a Europa, y dentro de España al norte y a las zonas costeras, lo que dio lugar a una desarticulación de los grupos sociales y de las bases económicas de los municipios, que se proyectó en los ciclos festivos. Los rituales y fiestas perdieron, por lo general, su funcionalidad como marcadores de los ritmos de trabajo y descanso de acuerdo con los ciclos agrarios y pasaron a estar regidos por pautas urbanas e industriales. Dejaron de ser periodos de impasse y regreso al pueblo de las personas que vivían y trabajaban próximas pero dispersas en los campos, para convertirse en espacios de reencuentro entre los emigrantes y los que permanecieron en la sierra, pero ya solo en torno a unas celebraciones concretas, las que se adaptaban a las vacaciones de la población desplazada, y no a todas. Con ello, los ciclos festivos se simplificaron y desaparecieron algunas celebraciones. En este contexto, los tiempos de la fiesta empezaron a experimentar modificaciones. Algunos rituales centrales, como las procesiones, se trasladaron a los fines de semana en numerosas localidades y, aunque en otras continuó respetándose el día de la advocación, los festejos se alargaron hasta el fin de semana más próximo para ampliar las posibilidades de participación de quienes no residían en la localidad. El cambio en las formas no ha supuesto una pérdida de su dimensión integradora e incluso ha contribuido a reforzarla con el añadido de nuevos grupos sociales. Son numerosas las fiestas y rituales que se han reproducido a lo largo del tiempo como expresiones culturales vivas, cambiantes, con mayor complejidad o simplificadas según el caso, pero que mantienen su funcionalidad como referentes de un "nosotros" colectivo, "el pueblo" concebido como comunidad de origen con unos valores sociales compartidos. 

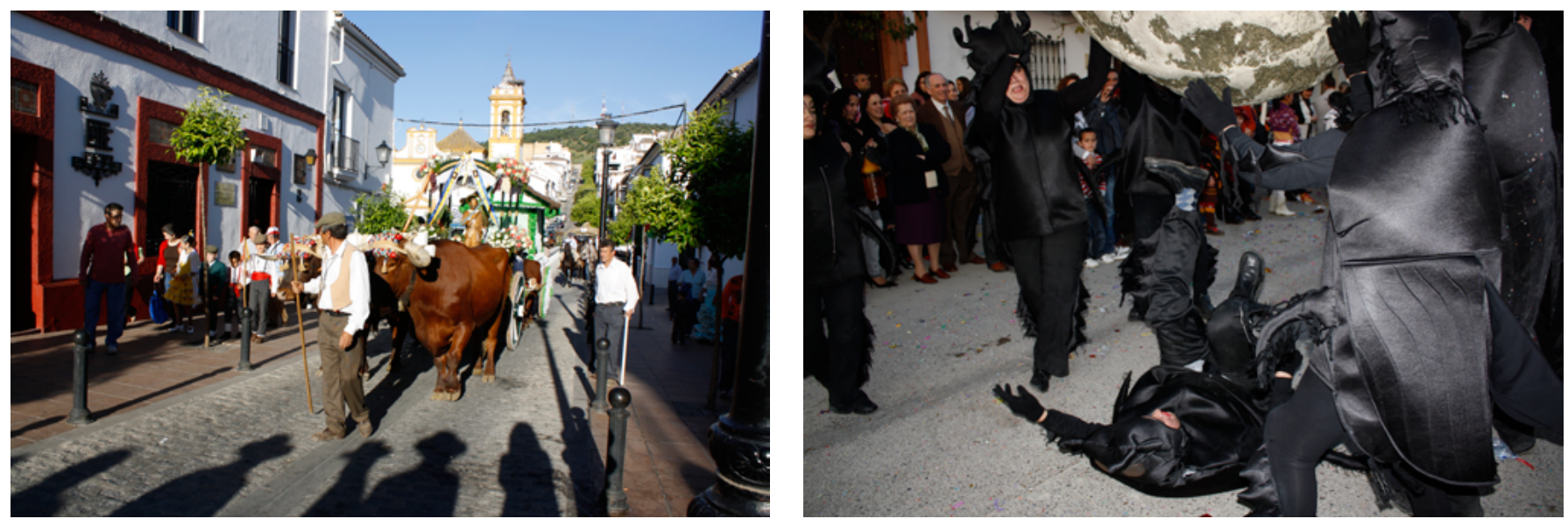

Escarabajos peloteros en el Carnaval de Puerto Serrano (izquierda)

Los rituales festivos más generalizados, por tener lugar en casi todos los municipios de la comarca, son la Semana Santa, las romerías, el Corpus, las ferias y las fiestas patronales, si bien presentan rasgos y grados de complejidad diferentes.

La Semana Santa tiene mucha importancia en la comarca y, salvo en El Bosque, en todos los municipios existen cofradías. Además, en Arcos de la Frontera, Setenil de las Bodegas, Espera, Olvera y Alcalá del Valle han sido declaradas de Interés Turístico Nacional. En todas ellas destacan elementos formales que otorgan un estilo propio a las procesiones o a la festividad y las dotan de una singularidad que marca la diferencia como colectivos, cuando se trata de grupos sociales concretos, o como comunidad local. Ejemplo de ello son Los Negros y Los Blancos de Setenil de las Bodegas, tradicionales "mitades" que se reproducen, con sus particularidades, en distintos municipios andaluces. Se trata de una peculiar forma de rivalidad ritual de carácter dual, a partir de la adscripción de la sociedad local a una u otra hermandad. También, el Auto sacramental de La Carrerita de San Juan en Alcalá del Valle o los paseos de los armaos de Arcos de la Frontera.

El proceso de asimilación de elementos de la Semana Santa sevillana, sobre todo, pero también malagueña, que se había generalizado en toda Andalucía en las pasadas décadas, está revirtiendo en muchas de estas localidades serranas y, como consecuencia, se están recuperando las formas más tradicionales de portar los pasos, así como las ropas y enseres que habían ido desapareciendo del espacio ritual. En este nuevo contexto, la singularidad y la vuelta a la tradición son igualmente elementos que están reforzando el sello diferenciador de unas localidades frente a las otras.

La fiesta del Corpus, que en muchas localidades ha perdido parte de su significación para convertirse exclusivamente en un acto litúrgico, mantiene su
Romería de San Isidro Labrador de Prado del Rey (arriba) 


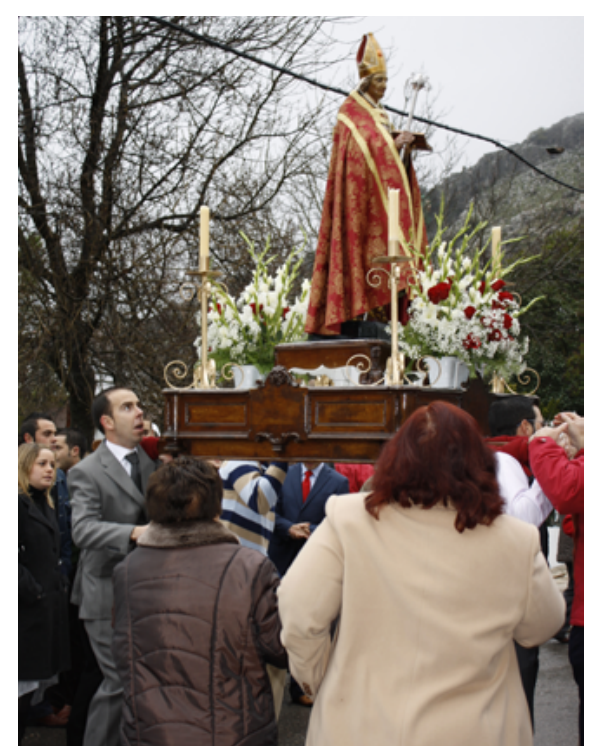

Procesión de San Blas de Benaocaz (arriba)

Procesión de la Virgen del Carmen de Grazalema (centro)

Calle ornamentada para el Corpus de El Gastor (derecha)
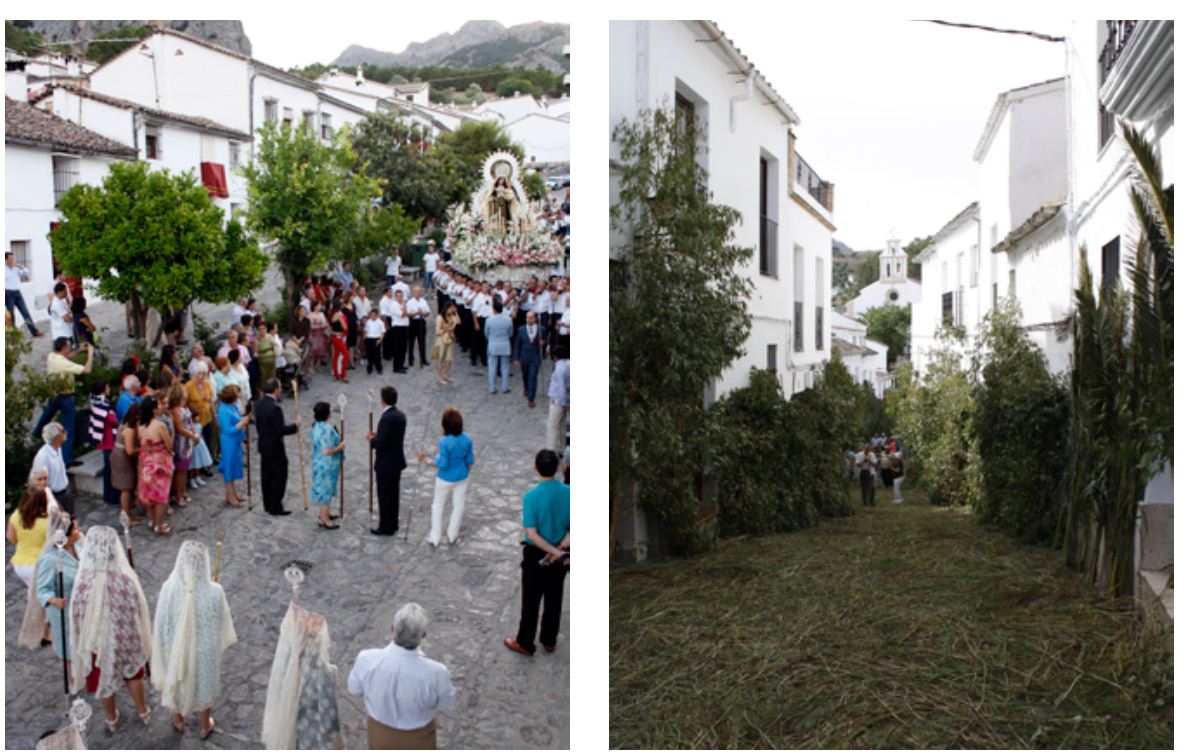

relevancia en Zahara de la Sierra y El Gastor. En ambas localidades destaca el ornamento con ramas y juncias que, por un día, convierte a estos pueblos blancos en bosques frondosos de especial colorido y vistosidad, acogiendo a un gran número de visitantes.

Las ferias suelen coincidir con las fiestas patronales, salvo en algunas poblaciones como Villamartín, Bornos o Espera. Muchas de ellas tienen su origen en antiguas ferias en torno a la compra-venta de ganado. Este tipo de encuentros fue perdiendo su función principal como consecuencia de los cambios socioeconómicos experimentados en la comarca a partir de los años sesenta, aunque se conservan en algunas localidades. Un ejemplo significativo es la feria de San Mateo en Villamartín, declarada de Interés Turístico Nacional.

Los festejos patronales son los que tienen mayor importancia en los pueblos más pequeños de la sierra. Como ya se ha mencionado, en ellos la celebración del día del patrón o patrona y la feria de la localidad suelen coincidir. La mayoría de estas celebraciones responden a un esquema similar. El ritual central se compone de una misa y la procesión en honor a la imagen protectora de la localidad y, junto a ello, hay una parte lúdica que incluye verbenas diurnas y nocturnas en la plaza principal, actividades culturales y/o deportivas y un final de fiesta con fuegos artificiales. Aunque los carnavales, el Corpus o la Semana Santa tienen una fuerte dimensión identitaria en varios municipios de la sierra, como Bornos (carnaval), El Gastor o Zahara de la Sierra (el Corpus) o Setenil de las Bodegas (la Semana Santa), es en las fiestas patronales donde se refuerzan, en mayor medida, los sentimientos de pertenencia a una comunidad simbólica representada por la localidad de origen e identificada con la imagen patronal. Son éstas las fechas en las que 

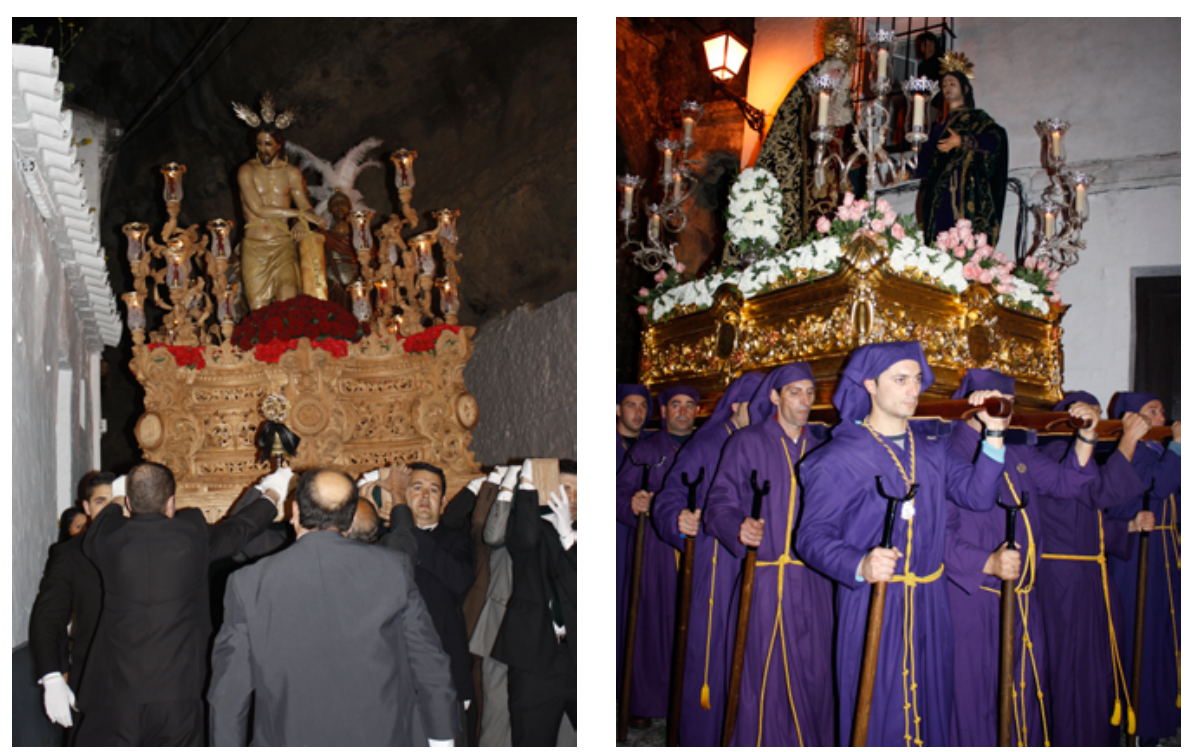

la población emigrante regresa a sus pueblos, coincidiendo con las vacaciones, al igual que lo hacen quienes residen en otras localidades próximas y mantienen un contacto más continuado con su lugar de origen. La participación en las fiestas, y en concreto en la procesión, manifiesta el deseo de pertenencia que se conserva en la distancia. La presencia, además, adquiere especial significación porque, en muchos casos, proyecta en el espacio ritual una fidelidad a la comunidad que se ha manifestado a través de los años. Entre otras cosas, a través de los apoyos económicos para compra de enseres, arreglo de imágenes y otras mejoras de patrimonio mueble e inmueble.

Las romerías responden a distintos esquemas. Unas consisten en traslados de las imágenes patronales a las ermitas; es el caso de la romería de la Malena de Puerto Serrano, o a las afueras del núcleo urbano, como la romería de San Antonio de Padua de El Bosque. Otras son peregrinaciones del pueblo a la ermita donde se encuentra la imagen, como ocurre en la romería de las Montañas de Villamartín o el Lunes de Quasimodo de Olvera. En ambos casos, con una clara función simbólica de apropiación del espacio ritual. Igualmente, por su carácter agrario, siguen siendo significativas en muchas localidades serranas las romerías de San Isidro Labrador, en especial, en Prado del Rey, Ubrique, Setenil de las Bodegas, Algodonales, Alcalá del Valle y Grazalema. En todas estas romerías, en mayor o menor medida, encontramos elementos propios de las de la baja Andalucía: Ios trajes rocieros o de flamenca, los cantes por sevillanas, la incorporación de un camino para hacer en comunidad o la presencia de carrozas, carretas y caballos.

Las Cruces de Mayo, muy generalizadas antes en todo el territorio andaluz, se celebran en la actualidad en Arcos de la Frontera, donde se han recu-

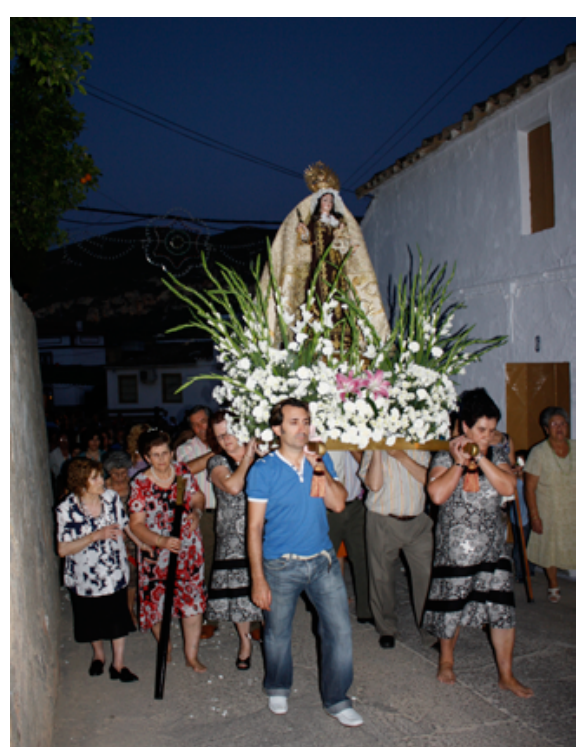

Procesión de la Virgen del Carmen de La Muela de Algodonales (arriba)

Procesión del Nazareno de Arcos de la Frontera (centro)

Procesión de los Blancos de Setenil de las Bodegas (izquierda) 


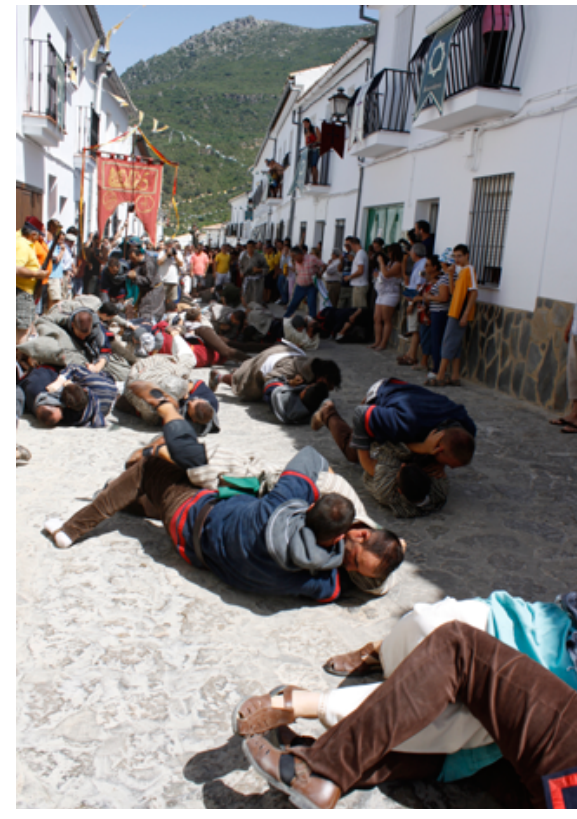

Moros y Cristianos (Las Luchas) de Benamahoma

perado a iniciativa del Ayuntamiento, con la participación de asociaciones y vecinos, y en Ubrique. El día de los Gamones es una de las fiestas más representativas de Ubrique. Este día se engalanan las calles, plazas y cruces y, por la noche, se encienden cientos de hogueras en las que se hacen crujir los gamones, unas varas recogidas previamente en los campos cercanos. Los carnavales, prohibidos durante la dictadura franquista como en el resto de España, se recuperaron en la mayoría de las poblaciones de la Sierra de Cádiz, fundamentalmente, a lo largo de los años ochenta. En la actualidad se celebran carnavales en casi todos ellas aunque con distinta relevancia. Destacan los carnavales de Bornos, Arcos de la Frontera, Ubrique, Puerto Serrano y Setenil de las Bodegas. Bornos conserva rasgos del carnaval rural, pero, en general, se han asimilado elementos carnavalescos del modelo gaditano y suelen ser habituales las actuaciones de chirigotas de Cádiz. Un caso singular es el de Puerto Serrano, donde se ha creado un modelo de agrupación carnavalesca diferente a las tradicionales gaditanas, en la que sus integrantes no cantan coplas y los elementos más relevantes, que componen una original puesta en escena, son el "tipo", la coreografía y los "armatostes" (objetos muy diversos y de distintos tamaños que complementan la escenografía).

Otras celebraciones más minoritarias responden al desarrollo de un modelo propio o que incluyen algún elemento singular dentro de la comarca, como rasgo identificador a nivel local. Es el caso de los toros enmaromaos de la fiesta de San Roque de Villaluenga del Rosario, las Fiestas Mayores de Benaocaz y de las Fiestas del Carmen de Grazalema. El toro ensogado por los cuernos recorre las calles del municipio mientras los corredores, sobre todo hombres pero en los últimos años también mujeres, citan, huyen, y hacen recortes al astado. El día de San Blas en Benaocaz el santo recorre el pueblo, sin itinerario establecido, bailando junto con los benaocaceños al ritmo enérgico de una charanga. $Y$ en Benamahoma tiene lugar la única fiesta de Moros y Cristianos de la comarca, en la que sobresalen los retos verbales, diálogos desafiantes $y$, en su mayor parte, improvisados, que intercambian los capitanes moro y cristiano y "las luchas" rituales en las que se enzarzan ellos y sus seguidores, rodando por el suelo emparejados en un abrazo. Son elementos rituales, ambos, que no están presentes en otras celebraciones de moros y cristianos.

En los últimos años se está impulsando la recuperación de rituales abandonados, se han potenciado los festejos patronales y, paralelamente, se están creando nuevas fiestas. Esto responde a una manera de entender los nuevos discursos sobre el patrimonio cultural, de resignificar la recuperación de lo tradicional, "de lo propio", como recurso dentro de una política local y comarcal destinada al fomento del turismo rural como un eje fundamental del desarrollo económico. Pero, igualmente, responde a la necesidad de frenar el despoblamiento de estos pueblos, de crear o recuperar momentos en los 
que se recrea la comunidad imaginada, de responder a las demandas de los diferentes colectivos sociales y de las diferentes sensibilidades que habitan los municipios. Por ello, es significativo que en las fiestas de mayor centralidad, sobre todo en las fiestas patronales, se tienda cada vez más a dedicar momentos de protagonismo específico para los distintos grupos de edad o agrupaciones de diverso tipo, que se concretan en comidas especiales, actividades y actuaciones. La necesidad de reforzar el sentido de comunidad, al mismo tiempo que las demandas de unas sociedades locales crecientemente heterogéneas, así como de rentabilizar, social y económicamente, las fiestas está conduciendo a una mayor complejidad de las mismas.

\section{BIBLIOGRAFÍA}

- Agudo TORRICO, J. (2001) Romerías, Ferias y Fiestas. En Conocer Andalucía: Gran Enciclopedia Andaluza del Siglo XXI. Vol. 6. Santander: Ediciones Tartessos, 2001, pp. 257-303 